\title{
Tissue Doppler in Ischemic Heart Disease
}

\author{
Ola Gjesdal and Thor Edvardsen \\ Oslo University Hospital and University of Oslo \\ Norway
}

\section{Introduction}

Tissue Doppler Echocardiography was introduced in the 1960s (Yoshida et al., 1961), and enabled the quantitative assessment of myocardial motion and deformation. The wide use of tissue Doppler as a research tool halted, however, until the early 1990s (Hatle \& Sutherland, 2000). Tissue Doppler is now available for high frame rates, wide sector angles and in combination with 2-dimiensional data acquisition. Although widely used in cardiovascular research, the clinical use is limited, probably due to the time consumption associated with special imaging protocols and tedious post processing. Nevertheless, tissue Doppler echocardiography has contributed to most of the available knowledge on the pathophysiology involved in myocardial contraction deficiency.

The experienced cardiologist can easily identify large myocardial infarcts by visual analysis of echocardiograms, but identification of a small MI may be challenging due to the modest changes in tissue properties. In ischemic tissue, the contractility is reduced and reduced deformation and deformation rate is observed. Due to differences in contractility among ischemic and adjacent healthy myocardium, the ischemic myocardium has a characteristic deformation pattern with stretch in early systole, reduced systolic shortening, and a delayed (postsystolic) shortening when the ventricular pressure decays. This early stretch and post systolic shortening pattern has been described both experimentally (Edvardsen, T. et al., 2002; Skulstad et al., 2002) and clinically (Gjesdal et al., 2008; Jamal et al., 1999; Voigt et al., 2004).

\section{Deformation indices}

Myocardial function was traditionally assessed by tissue Doppler by the measurement of myocardial velocity and displacement indices in directions parallel to the ultrasound beam direction. These indices allowed quantitative assessment of myocardial function in the longitudinal direction, but could not differentiate velocities caused by deformation in the myocardium from velocities caused by displacement and tethering from adjacent structures.

The deforming heart can be assessed by evaluation of tissue velocities or displacement, deformation (strain) or rate of deformation (strain rate).

The Doppler shift utilized for deformational assessment in tissue Doppler echocardiography is a measure directly correlated to tissue velocity, and strain or strain rate measurements are automatically derived by integration or derivation of the spatial velocity distribution (Figure 
1). During contraction, the apex is relatively stationary and the strain is relatively equally distributed in the different left ventricular compartments. There is therefore a natural gradient of velocity and displacement in the heart, with higher values observed towards the basal part of the heart. Tethering (pulling) by healthy adjacent myocardium, and translational cardiac motion can thus influence the velocities and displacements of diseased myocardium. When these indices are assessed, the position of the region of interest must therefore be evaluated together with the velocity information (Skulstad et al., 2004).

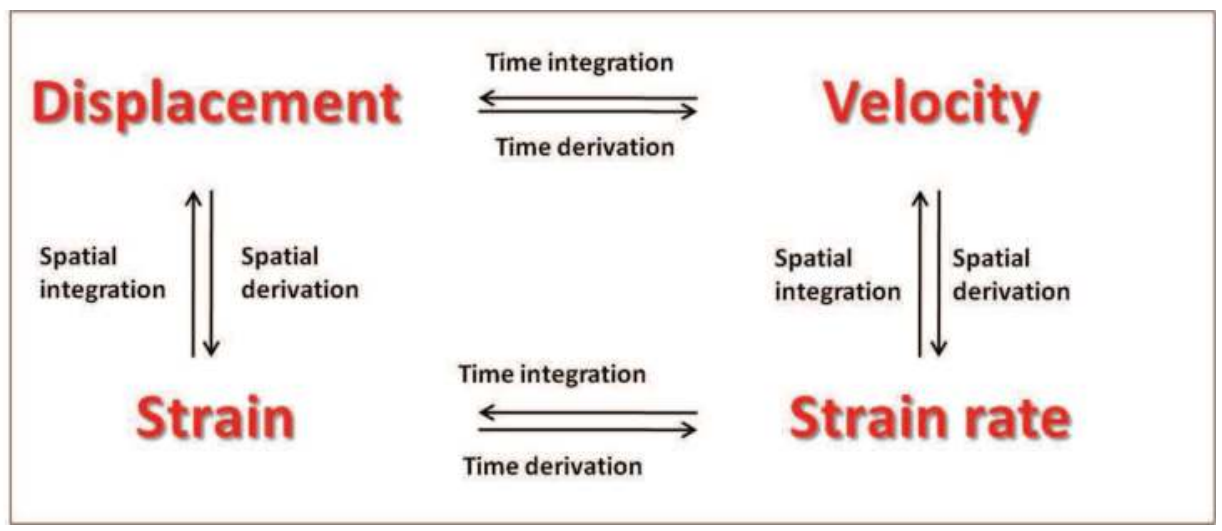

Fig. 1. Mathematical relation between deformation indices

In an attempt to establish a measure that was more specific for myocardial properties the principle of calculating myocardial strain rate from echocardiographic data was introduced (Quinones et al., 1974). This is analogous to the earlier approach to calculate strain rate or "normalized velocities" from apex cardiographic tracings, and the concept of myocardial strain was defined as fractional tissue deformation in response to applied force or stress (Mirsky et al., 1972). In that context, strain represents fractional change of tissue length and is expressed in a dimensionless unit as percent shortening or lengthening (Lagrangian formula). In an effort to improve the ability of TDI to measure regional function, TDIderived real time strain rate was introduced (Heimdal et al., 1998). Strains are more uniformly distributed within the LV myocardium than tissue velocities, and the assessment of myocardial strain by TDI thus simplifies the analysis of regional contractile function by providing an objective parameter of myocardial deformation. Strain is a relatively new index of myocardial function that describes myocardial deformation as the relative change in myocardial segment length over time (D'hooge, J. et al., 2002), and provides information on segmental or global myocardial deformation (Gjesdal et al., 2007). Strain (deformation) or strain rate (rate of deformation) can be assessed in patients by echocardiography using tissue Doppler or speckle tracking echocardiography (Dandel \& Hetzer, 2009) or with tagged MRI (Edvardsen \& Rosen, 2005), and in experimental studies by sonomicrometry (Urheim et al., 2000). The indices have proven superior to established indices of myocardial function to assess myocardial infarct size (Becker et al., 2006; Chan et al., 2006; Gjesdal et al., 2008; Vartdal et al., 2007), hypertrophic cardiomyopathy (Serri et al., 2006), and in metabolic syndrome (Gong et al., 2009), ads incremental value in predicting outcome in cardiovascular 
disease (Ingul, C. B. et al., 2007), and predicts arrhythmic events after myocardial infarct (Haugaa et al., 2009).

Strain and strain rate (SR) were developed as clinical indices of regional myocardial deformation (Edvardsen et al., 2001; Gotte et al., 2001; Mirsky \& Parmley, 1973; Rademakers et al., 1994; Zhang et al., 2005) and have been introduced and validated using tagged MRI and sonomicrometry (Derumeaux et al., 2001; Edvardsen, T. et al., 2002; Urheim et al., 2000). Strain is defined as tissue elongation relative to length; usually the length at end diastole (Lagrangian strain) but instantaneous length is also used (Eulerian strain). A positive strain value refers to elongation, whereas a negative strain value describes shortening. Strain and strain rate are related through temporal derivation or integration, respectively. Therefore, negative systolic strain and strain rate values describe a normal contracting myocardial segment. Three main systolic deformation patterns form perpendicular axes in the heart's internal coordinate system (D'hooge et al., 2000); longitudinal shortening, circumferential shortening and radial thickening (Figure 2). In a direct comparison between strain, displacement and ejection velocity, strain by tissue Doppler was found to be superior to describe regional myocardial function, both in an animal model, and in humans(Skulstad et al., 2006).

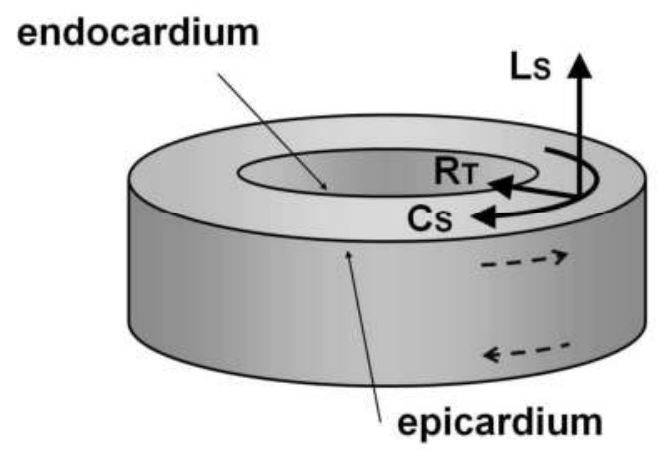

Fig. 2. The heart's coordinate system. Longitudinal shortening (Ls), Circumferential shortening $\left(\mathrm{C}_{\mathrm{S}}\right)$ and Radial Thickening $\left(\mathrm{R}_{\mathrm{T}}\right)$ is displayed

Doppler derived measures are angle dependent, and the assessment of global function is limited by angulations of apical segmental myocardium relative to the ultrasound beam direction. To overcome this problem, assessment of mitral plane velocities or displacement has been proposed as an index of global LV function (Alam et al., 1990; Alam, M. et al., 1992; Hoglund et al., 1989; Simonson \& Schiller, 1989). Due to tethering from the mid-ventricular and apical segments, the displacement at the base of the left ventricle reflects the average deformation of the LV walls. When opposing walls are evaluated during the same heartbeat, the potential misjudgment caused by apical rocking is reduced to a minimum. Mitral annulus displacement and velocity analyses by TDI has been validated in the clinical setting, is well established and widely available. The method requires dedicated imaging protocols and is angle dependant, but might be more robust compared to speckle tracking imaging 
when the acoustic window is poor. Mitral annulus displacement has proven to be robust and reproducible (Hayashi et al., 2006), and has demonstrated good ability to predict prognosis following myocardial infarct (Brand et al., 2002). Mitral annulus displacement can also be normalized for end diastolic LV length (normalized Mitral annulus Displacement), an index which corresponds to global strain (Gjesdal et al., 2009).

To eliminate the problem of angle-dependency in Doppler-derived deformation analyses, strain measurement based on two-dimensional speckle-tracking echocardiography (2D-STE) has recently been developed (Amundsen et al., 2006; Cho et al., 2006; D'hooge, J. et al., 2002; Helle-Valle et al., 2005; Leitman et al., 2004). Natural acoustic markers (speckles) visualized by gray scale imaging form patterns within myocardial tissue. Dedicated software identifies the speckle patterns, and myocardial deformation assessed based on deformational changes on a frame-to-frame basis. Strain is calculated for each LV-segment as the average relative deformation in circumferential, longitudinal or radial directions (Becker et al., 2006; Chan et al., 2006; Vartdal et al., 2007) and the method furthermore enables assessment of LV-rotation and twist (Helle-Valle et al., 2005). The method is semi-automatic and relatively independent of angle. Spatial resolution is nearly constant with depth in the direction of the ultrasound beam, while the spatial resolution orthogonal to the beam direction is constant with depth with a linear array transducer, and decreases slightly with depth when a sector or phased array transducer is used. Since speckle tracking echocardiography is a developing methodology for assessment of the same indices that are assessed by tissue Doppler echocardiography, this will also be covered briefly. The implementation of TDI in daily clinical work has been relatively slow and most echocardiographic laboratories do not apply TDI as a routine diagnostic method.

\section{Infarct assessment}

Direct assessment of myocardial infarct by histopathology is the gold standard for infarct sizing, and is an option in post-mortem studies, in animal studies, and in studies on the explanted heart (Kim et al., 1999; Medrano et al., 1996). Biochemical infarct sizing is based on the correlation between the amount of damaged myocardium and release to the blood pool of specific markers of cardiac necrosis. Peak values correlate to infarct size, but the accuracy of the methods depends on correct timing of the blood sampling in relation to the ischemic event (Gibbons et al., 2004). Visualization of MI by imaging techniques is based on differences in tissue properties among normal and infarcted tissue. In CE-MRI, the infarcted myocardium is highlighted due to retention of contrast medium in the infarcted tissue, while positron emission tomography (PET) and single photon emission computed tomography (SPECT), are based on visualization of viable non-infarcted myocardium due to preserved glucose metabolism and retention of radioactive tracers in viable myocytes, respectively (Gibbons et al., 2004). In echocardiography and in cine- and tagged MRI imaging, changes in cardiac motion pattern, deformation, or changes in LV pumping performance form the basis of infarct sizing.

Myocardial contraction is severely reduced within scars, and systolic deformation of the left ventricle therefore decreases with increasing myocardial scar load (Chan et al., 2006; Hoglund et al., 1989; Skulstad et al., 2006; Vartdal et al., 2007). Assessment of myocardial deformation at a global or segmental level thus represents alternatives to the direct assessment of myocardial scar load by CE-MRI (Figure 3). Echocardiographic scanners are 
less expensive, widely distributed, and are mastered by most cardiologists, and enables myocardial deformation assessment by a variety of methods. Evaluation of LV-deformation has traditionally been performed by assessment of the relative volume reduction during systole (Left ventricular ejection fraction, LVEF), by visual assessment of the wall thickening in individual LV-segments during systole (Wall motion score, WMS) (Lang et al., 2005), or by assessment of the longitudinal LV-shortening or rate of shortening (mitral annulus displacement or velocity) (Simonson \& Schiller, 1989).

Echocardiographic assessment of LVEF is easily available and feasible, but does not provide information on segmental LV-function. Evaluation of regional function by analyses of endocardial motion or local wall thinning and thickening characteristics is user dependent and requires well-trained personnel. Measurement of longitudinal LV-deformation by mitral annulus (MA) displacement or velocity can be performed by tissue Doppler imaging (TDI), pulsed TDI or M-mode echocardiography (Hayashi et al., 2006). Assessment is relatively easy, but the reference values differ among the methods. Furthermore, the methods do not provide information on segmental deformation, and regional deformation may be influenced by tethering or apical rocking. MA-displacement, however, predicts future events in patients with myocardial infarction, heart failure or hypertensive heart disease (Ballo et al., 2008; Hillenbrand et al., 2000; Willenheimer, R. et al., 1997).
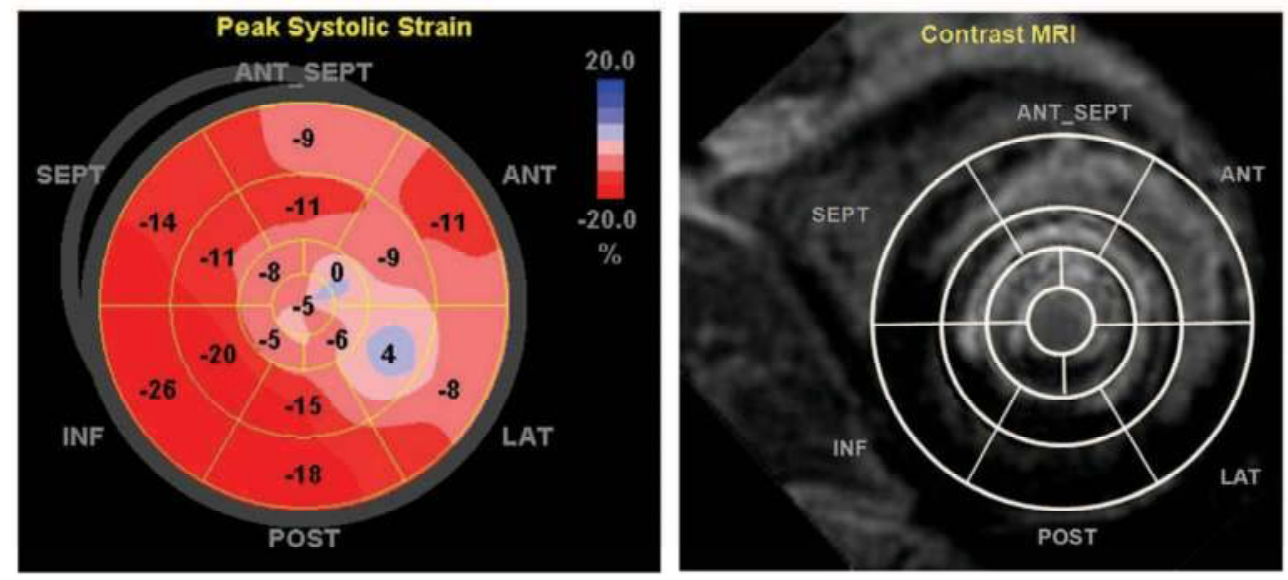

Fig. 3. Bulls eye plot of peak systolic longitudinal strain by speckle tracking echocardiography (left) and gadolinium contrast MRI (right). The center of the plot represents apex, and the rim represents the basal LV segments

Low systolic myocardial velocities in ventricles with myocardial damage, hypertrophy and cardiomyopathy have been demonstrated by several authors (Bach et al., 1996; Gorcsan, III et al., 1996; Miyatake et al., 1995; Uematsu et al., 1995). Mitral annular and myocardial longitudinal velocity measurements have been used in several studies to characterize systole in normal individuals and in different heart diseases (Fukuda et al., 1998; Gulati et al., 1996; Oki et al., 1999; Pai \& Gill, 1998; Wilkenshoff et al., 1998). Generally, systolic longitudinal velocity was reduced in most heart diseases. This longitudinal approach has also been useful to describe the diastolic function in normal subjects and patients with LV 
hypertrophy showing a decrease in VE with age and in LV hypertrophy (Rodriguez et al., 1996). Several conditions are thus responsible for decreased myocardial systolic and diastolic velocities and myocardial single finding of reduced velocity. Based on the available literature, it is likely that focus on the highest systolic velocity or deformation is not sufficient to characterize ischemia from other diseases affecting the contraction of the heart.

\section{Validation studies}

Tissue Doppler derived strain and strain rate have been validated using tagged MRI and sonomicrometry in humans and in animal studies (Derumeaux et al., 2001; Edvardsen et al., 2002; Urheim et al., 2000). Myocardial longitudinal strain was assessed as the time integral of regional Doppler velocity gradients in a dog model, and compared with strain derived from sonomicrometry crystals placed near the LV apex and base, respectively (Derumeaux et al., 2001; Edvardsen, T. et al., 2002; Urheim et al., 2000).Comparisons during baseline, apical ischemia and preload alterations demonstrated good correlations $(\mathrm{r}=0.92, \mathrm{p}<0.01)$.

In human studies longitudinal myocardial Doppler velocities have been shown to decrease progressively from base to apex, while myocardial strain rates and strains are uniformly distributed among all segments (Edvardsen, T. et al., 2002). Comparisons between myocardial longitudinal strains by SDE and tagged-MRI showed excellent correlations $(\mathrm{r}=0.89$ and $\mathrm{r}=0.96$, for longitudinal and radial strains respectively $(\mathrm{p}<0.001)$, in healthy individuals, infarct patients, and during stress echocardiography.

\section{Acute ischemic heart disease}

\subsection{Deformation characteristics}

During acute ischemia, the contractility of the ischemic myocardium is reduced. Postsystolic shortening was identified as a sign of viability in a dog model of ischemic heart disease (Takayama et al., 1996), and tissue Doppler enabled the characterization of regional wall motion disturbances during ischemia and reperfusion (Derumeaux et al., 1998). Also in humans, abnormal postsystolic contraction was observed during ischemia (Jamal et al., 1999). Deformation assessment by strain and strain rate demonstrated better ability to evaluate ischemic myocardium compared to velocity based indices in animal models (Hashimoto et al., 2003) and human studies (Edvardsen, T. et al., 2002; Jamal et al., 2002; Zhang et al., 2005), and provide information on small changes in function over time (Ingul et al., 2005),

In a study during and after angioplasty in humans, three major characteristics were identified for the systolic velocity pattern of ischemic myocardium (Edvardsen et al., 2000; Edvardsen et al., 2001). When comparing the ischemic regions of LV with the nonischemic regions, the ischemic region was recognized by early systolic stretch and reduced peak systolic shortening, followed by a postsystolic shortening when the LV pressure decays during isovolumetric relaxation and early diastole (Figure 4). When the ischemia becomes more severe, the segment gradually becomes passive, and the deformation depends on the passive elastic properties of the myocardial tissue (Skulstad et al., 2002). 


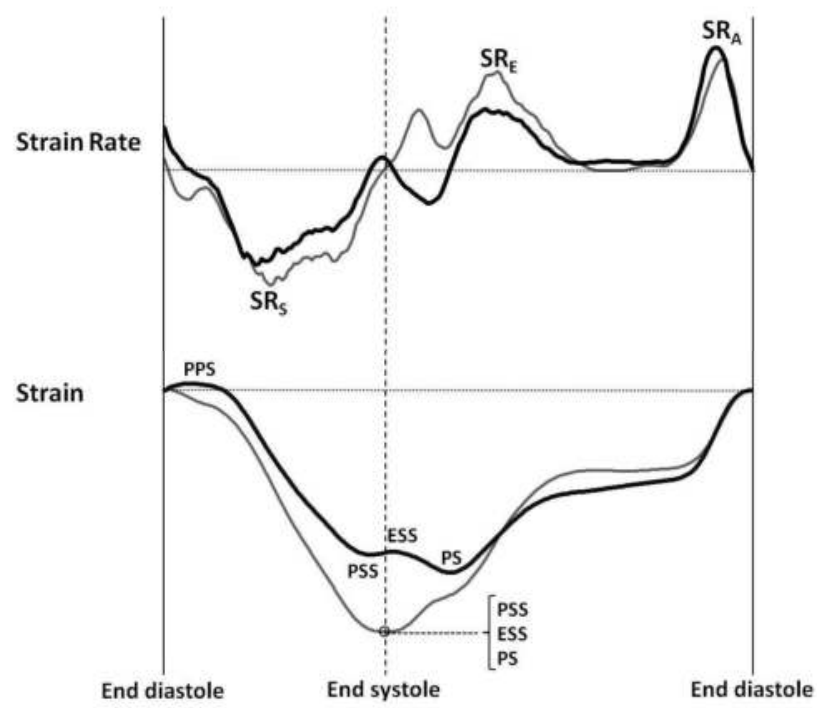

Fig. 4. Strain rate and strain from typical normal (grey) and ischemic (black) myocardium. Ischemic myocardium is characterized by an early peak positive strain (PPS), and peak systolic strain (PSS) is typically lower than end systolic strain (ESS). A post systolic shortening is often seen, and peak strain (PS) therefore occurs after end systole

During ischemia, adjacent myocardium also display altered deformation characteristics. This might be caused by stunning or transient ischemia, but also by alterations in local loading conditions. Remote myocardium generally has been thought to increase the contraction in a compensatory manner to accomplish the demands to cardiac output. This mechanism could be caused by neuro-hormonal activation, but also but the Frank-Starling mechanism secondary to the increased preload of the ischemic heart.

Recently, strain by Doppler and speckle tracking was demonstrated to display similar ability to separate among levels of transmurality in acute ST elevation myocardial infarction, but that reproducibility was somewhat better for speckle tracking derived strain (Sjoli et al., 2009). Postsystolic shortening has also been demonstrated in approximately one third of segments in healthy individuals, and indexation of postsystolic shortening relative to peak systolic shortening has therefore been suggested (Voigt, J. U. et al., 2003). Systolic strain by vector velocity imaging is also found to correlate with infarct in the acute phase, and peak systolic strain was a better predictor of infarct than the post systolic shortening index (Jurcut et al., 2008).

\subsection{Identification of area at risk}

Strain imaging by tissue Doppler echocardiography shortly after PCI for acute myocardial infarct correlated strongly with global infarct size assessed by delayed enhancement MRI 9 months later (Vartdal et al., 2007). Similar results were also found for speckle tracking echocardiography (Sjoli et al., 2009). Moreover, the strain value correlated with infarct transmurality level, suggesting that this index might be useful for prognostication. 


\subsection{Non ST elevation infarction}

Global strain by speckle tracking deteriorates in non ST-elevation patients while waiting for angiography, and the patients with occlusion did not recover by revascularization, thus suggesting a potential benefit from a more aggressive strategy in these patients (Grenne et al., 2010). Strain measured immediately before revascularization was found to correlate significantly with infarct size assessed by delayed enhancement MRI also in non ST-elevation infarcts (Eek et al., 2010), and presence of reduced function in 4 or more adjacent segments was shown to predict coronary occlusion with high accuracy (Eek et al., 2010).

\section{Chronic ischemic heart disease}

\subsection{Deformation characteristics}

In chronic ischemic heart disease, the infarcted area has transformed to scar tissue with increased resistance to passive stretch. As a consequence, early systolic stretch is a less common finding. There is often, however, ischemic areas and areas with subendocardial infarct present adjacent to the infarcted areas, and early stretch can be identified in these areas. In the MESA study, reduced myocardial deformation was found in healthy individuals with increased coronary artery calcification (Edvardsen et al., 2006).

\subsection{Estimation of infarct size and level of transmurality}

In chronic myocardial infarct, strain values assessed by tissue Doppler or speckle tracking echocardiography are reduced with increasing level of transmural infarct distribution (Becker et al., 2006; Chan et al., 2006; Gjesdal et al., 2007; Sachdev et al., 2006; Weidemann et al., 2003), both at the segmental, at the global, and at a territorial level (Gjesdal et al., 2008). This is interesting, since segments with transmural infarct defined as more than $50 \%$ of the segment mass is less likely to benefit from revascularization.

Also the MA-displacement have demonstrated to be reduced both in patients with acute(Hoglund et al., 1989; Skulstad et al., 2006; Stoylen \& Skjaerpe, 2003) or chronic infarct (Alam, M. et al., 1992) when compared to controls, and the reduction was greater in infarctrelated LV-walls when compared to remote LV-walls. Normalized mitral annulus displacement has also demonstrated good correlation with myocardial infarct size in chronic ischemic heart disease (Gjesdal et al., 2009).

\subsection{Risk stratification for arrhythmias}

Recently, post myocardial infarct patients with indication for implantable cardioverterdefibrillator (ICD) were followed for arrhythmias requiring appropriate ICD therapy (Haugaa et al., 2009). In the patients with arrhythmia the dispersion of peak strain, calculated as standard deviation of time to maximal strain for all segments, was increased compared to patients who did not require therapy. Moreover, the global strain value was better in the patients without arrhythmia compared to the ones who received ICD therapy.

\subsection{Stress testing}

Tissue Doppler echocardiography has been used to quantify segmental function during exercise testing by velocity imaging (Pasquet et al., 1999), and has been demonstrated to predict functional recovery from revascularization (Schneider et al., 2005). When comparing 
deformation imaging and velocity imaging for the detection of regional inducible ischemia during dobutamine stress echocardiography, deformation indices demonstrated superior ability to detect ischemia compared to velocity based indices (Voigt et al., 2004). Moreover, in another study, postsystolic shortening demonstrated the best ability to identify stress induced ischemia after normalization to peak deformation, since postsystolic shortening also occurred to some extent in healthy segments (Voigt, J. U. et al., 2003). Strain and strain rate had been found superior to wall motion score to identify angiographic significant stenoses (Ingul, C. B. et al., 2007), and also to predict outcomes in patients admitted to stress echocardiography for suspected coronary heart disease (Ingul, C. B. et al., 2007).

\section{Prognosis}

Assessment of strain early following myocardial infarction predicts remodeling defined as more than 15\% increase in end diastolic volume (Park et al., 2008). Global LV function assessed by tissue Doppler measurements of the mitral annulus displacement predicts events in chronic infarction (Brand et al., 2002) and congestive heart failure (Willenheimer, R. B. et al., 1997). The addition of strain rate during stress echocardiography added prognostic value over traditional risk factors and echocardiographic parameters (Stanton, T. et al., 2009), and an association between resting deformation indices and events was also demonstrated in people referred to echocardiography (Stanton, T. et al., 2009). Global strain by speckle tracking echocardiography was assessed within 48 hours of myocardial infarct in 659 patients, and found to be superior to LVEF and WMSI to predict mortality and clinical Events (Antoni et al., 2010).

\section{Conclusions}

All indices of myocardial function demonstrate reduced systolic deformation in infarcted myocardium. The deformation gradually reduces with increasing infarct size and transmural distribution. Ischemic tissue is characterized not only by reduced peak deformation, but also by an altered deformation pattern characterized by early systolic stretch and post systolic shortening.

\section{References}

Alam M., Hoglund C., Thorstrand C. Longitudinal systolic shortening of the left ventricle: an echocardiographic study in subjects with and without preserved global function. Clin Physiol 1992;12:443-52.

Alam M., Hoglund C., Thorstrand C., Hellekant C. Haemodynamic significance of the atrioventricular plane displacement in patients with coronary artery disease. Eur Heart J 1992;13:194-200.

Alam M, Hoglund C, Thorstrand C, Philip A. Atrioventricular plane displacement in severe congestive heart failure following dilated cardiomyopathy or myocardial infarction. J Intern Med 1990;228:569-75.

Amundsen BH, Helle-Valle T, Edvardsen T, Torp H, Crosby J, Lyseggen E, Stoylen A, Ihlen H, Lima JA, Smiseth OA, Slordahl SA. Noninvasive myocardial strain measurement by speckle tracking echocardiography: validation against 
sonomicrometry and tagged magnetic resonance imaging. J Am Coll Cardiol 2006;47:789-93.

Antoni ML, Mollema SA, Delgado V, Atary JZ, Borleffs CJW, Boersma E, Holman ER, van der Wall EE, Schalij MJ, Bax JJ. Prognostic importance of strain and strain rate after acute myocardial infarction. European Heart Journal 2010;31:1640-7.

Bach DS, Armstrong WF, Donovan CL, Muller DW. Quantitative Doppler tissue imaging for assessment of regional myocardial velocities during transient ischemia and reperfusion. Am Heart J 1996;132:721-5.

Ballo P, Barone D, Bocelli A, Motto A, Mondillo S. Left ventricular longitudinal systolic dysfunction is an independent marker of cardiovascular risk in patients with hypertension. Am J Hypertens 2008;21:1047-54.

Becker M, Hoffmann R, Kuhl HP, Grawe H, Katoh M, Kramann R, Bucker A, Hanrath P, Heussen N. Analysis of myocardial deformation based on ultrasonic pixel tracking to determine transmurality in chronic myocardial infarction. Eur Heart J 2006;27:2560-6.

Brand B, Rydberg E, Ericsson G, Gudmundsson P, Willenheimer R. Prognostication and risk stratification by assessment of left atrioventricular plane displacement in patients with myocardial infarction. Int J Cardiol 2002;83:35-41.

Chan J, Hanekom L, Wong C, Leano R, Cho GY, Marwick TH. Differentiation of subendocardial and transmural infarction using two-dimensional strain rate imaging to assess short-axis and long-axis myocardial function. J Am Coll Cardiol 2006;48:2026-33.

Cho GY, Chan J, Leano R, Strudwick M, Marwick TH. Comparison of two-dimensional speckle and tissue velocity based strain and validation with harmonic phase magnetic resonance imaging. Am J Cardiol 2006;97:1661-6.

D'hooge J., Bijnens B., Thoen J., Van de Werf F., Sutherland G. R., Suetens P. Echocardiographic strain and strain-rate imaging: a new tool to study regional myocardial function. IEEE Trans Med Imaging 2002;21:1022-30.

D'hooge J, Heimdal A, Jamal F, Kukulski T, Bijnens B, Rademakers F, Hatle L, Suetens P, Sutherland GR. Regional strain and strain rate measurements by cardiac ultrasound: principles, implementation and limitations. Eur J Echocardiogr 2000;1:154-70.

D'hooge J., Konofagou E., Jamal F., Heimdal A., Barrios L., Bijnens B., Thoen J., Van de Werf F., Sutherland G., Suetens P. Two-dimensional ultrasonic strain rate measurement of the human heart in vivo. IEEE Trans Ultrason Ferroelectr Freq Control 2002;49:2816.

Dandel M, Hetzer R. Echocardiographic strain and strain rate imaging - Clinical applications. International Journal of Cardiology 2009;132:11-24.

Derumeaux G, Loufoua J, Pontier G, Cribier A, Ovize M. Tissue Doppler imaging differentiates transmural from nontransmural acute myocardial infarction after reperfusion therapy. Circulation 2001;103:589-96.

Derumeaux G, Ovize M, Loufoua J, ndre-Fouet X, Minaire Y, Cribier A, Letac B. Doppler tissue imaging quantitates regional wall motion during myocardial ischemia and reperfusion. Circulation 1998;97:1970-7. 
Edvardsen T, Aakhus S, Endresen K, Bjomerheim R, Smiseth OA, Ihlen H. Acute regional myocardial ischemia identified by 2-dimensional multiregion tissue Doppler imaging technique. J Am Soc Echocardiogr 2000;13:986-94.

Edvardsen T, Detrano R, Rosen BD, Carr JJ, Liu K, Lai S, Shea S, Pan L, Bluemke DA, Lima JA. Coronary artery atherosclerosis is related to reduced regional left ventricular function in individuals without history of clinical cardiovascular disease: the Multiethnic Study of Atherosclerosis. Arterioscler Thromb Vasc Biol 2006;26:206-11.

Edvardsen T., Gerber B. L., Garot J., Bluemke D. A., Lima J. A., Smiseth O. A. Quantitative assessment of intrinsic regional myocardial deformation by Doppler strain rate echocardiography in humans: validation against three-dimensional tagged magnetic resonance imaging. Circulation 2002;106:50-6.

Edvardsen T, Rosen BD. Why do we need magnetic resonance imaging in cardiology? Scand Cardiovasc J 2005;39:260-3.

Edvardsen T, Skulstad H, Aakhus S, Urheim S, Ihlen H. Regional myocardial systolic function during acute myocardial ischemia assessed by strain Doppler echocardiography. J Am Coll Cardiol 2001;37:726-30.

Edvardsen T., Urheim S., Skulstad H., Steine K., Ihlen H., Smiseth O. A. Quantification of left ventricular systolic function by tissue Doppler echocardiography: added value of measuring pre- and postejection velocities in ischemic myocardium. Circulation 2002;105:2071-7.

Eek C, Grenne B, Brunvand H, Aakhus S, Endresen K, Smiseth OA, Edvardsen T, Skulstad $\mathrm{H}$. Strain echocardiography predicts acute coronary occlusion in patients with nonST-segment elevation acute coronary syndrome. Eur J Echocardiogr 2010;11:501-8.

Fukuda K, Oki T, Tabata T, Iuchi A, Ito S. Regional left ventricular wall motion abnormalities in myocardial infarction and mitral annular descent velocities studied with pulsed tissue Doppler imaging. J Am Soc Echocardiogr 1998;11:841-8.

Gibbons RJ, Valeti US, Araoz PA, Jaffe AS. The quantification of infarct size. J Am Coll Cardiol 2004;44:1533-42.

Gjesdal O, Helle-Valle T, Hopp E, Lunde K, Vartdal T, Aakhus S, Smith HJ, Ihlen H, Edvardsen T. Non-Invasive Separation of Large, Medium and Small Reperfused Myocardial Infarcts. A Comprehensive Tissue Doppler and Speckle Tracking Echocardiography Study. Circ Cardiovascular Imaging 2008;1:189-96.

Gjesdal O, Hopp E, Vartdal T, Lunde K, Helle-Valle T, Aakhus S, Smith HJ, Ihlen H, Edvardsen T. Global longitudinal strain measured by two-dimensional speckle tracking echocardiography is closely related to myocardial infarct size in chronic ischaemic heart disease. Clin Sci (Lond) 2007;113:287-96.

Gjesdal O, Vartdal T, Hopp E, Lunde K, Brunvand H, Smith HJ, Edvardsen T. Left ventricle longitudinal deformation assessment by mitral annulus displacement or global longitudinal strain in chronic ischemic heart disease: are they interchangeable? J Am Soc Echocardiogr 2009;22:823-30.

Gong HP, Tan HW, Fang NN, Song T, Li SH, Zhong M, Zhang W, Zhang Y. Impaired left ventricular systolic and diastolic function in patients with metabolic syndrome as assessed by strain and strain rate imaging. Diabetes Research and Clinical Practice 2009;83:300-7. 
Gorcsan J, III, Gulati VK, Mandarino WA, Katz WE. Color-coded measures of myocardial velocity throughout the cardiac cycle by tissue Doppler imaging to quantify regional left ventricular function. Am Heart J 1996;131:1203-13.

Gotte MJ, van Rossum AC, Twisk JWR, Kuijer JPA, Marcus JT, Visser CA. Quantification of regional contractile function after infarction: strain analysis superior to wall thickening analysis in discriminating infarct from remote myocardium. J Am Coll Cardiol 2001;37:808-17.

Grenne B, Eek C, Sjoli B, Skulstad H, Aakhus S, Smiseth OA, Edvardsen T, Brunvand H. Changes of Myocardial Function in Patients with Non-ST-Elevation Acute Coronary Syndrome Awaiting Coronary Angiography. American Journal of Cardiology 2010;105:1212-8.

Gulati VK, Katz WE, Follansbee WP, Gorcsan J, III. Mitral annular descent velocity by tissue Doppler echocardiography as an index of global left ventricular function. Am J Cardiol 1996;77:979-84.

Hashimoto I, Li X, Hejmadi BA, Jones M, Zetts AD, Sahn DJ. Myocardial strain rate is a superior method for evaluation of left ventricular subendocardial function compared with tissue Doppler imaging. J Am Coll Cardiol 2003;42:1574-83.

Hatle L, Sutherland GR. Regional myocardial function--a new approach. Eur Heart J 2000;21:1337-57.

Haugaa KH, Smedsrud MK, Kongsgaard E, Smiseth OA, Amlie JP, Edvardsen T. Left Ventricular Global Strain Is More Accurate Than EF as a Marker of Arrhythmic Events After Myocardial Infarction. Journal of the American College of Cardiology 2009;53:A262.

Hayashi SY, Lind BI, Seeberger A, do Nascimento MM, Lindholm BJ, Brodin LA. Analysis of mitral annulus motion measurements derived from M-mode, anatomic M-mode, tissue Doppler displacement, and 2-dimensional strain imaging. J Am Soc Echocardiogr 2006;19:1092-101.

Heimdal A, Stoylen A, Torp H, Skjaerpe T. Real-time strain rate imaging of the left ventricle by ultrasound. J Am Soc Echocardiogr 1998;11:1013-9.

Helle-Valle T, Crosby J, Edvardsen T, Lyseggen E, Amundsen BH, Smith HJ, Rosen BD, Lima JA, Torp H, Ihlen H, Smiseth OA. New noninvasive method for assessment of left ventricular rotation: speckle tracking echocardiography. Circulation 2005;112:3149-56.

Hillenbrand HB, Lima JA, Bluemke DA, Beache GM, McVeigh ER. Assessment of myocardial systolic function by tagged magnetic resonance imaging. J Cardiovasc Magn Reson 2000;2:57-66.

Hoglund C, Alam M, Thorstrand C. Effects of acute myocardial infarction on the displacement of the atrioventricular plane: an echocardiographic study. J Intern Med 1989;226:251-6.

Ingul C. B., Rozis E., Slordahl S. A., Marwick T. H. Incremental value of strain rate imaging to wall motion analysis for prediction of outcome in patients undergoing dobutamine stress echocardiography. Circulation 2007;115:1252-9.

Ingul CB, Stoylen A, Slordahl SA. Recovery of stunned myocardium in acute myocardial infarction quantified by strain rate imaging: a clinical study. J Am Soc Echocardiogr 2005;18:401-10. 
Ingul C. B., Stoylen A., Slordahl S. A., Wiseth R., Burgess M., Marwick T. H. Automated analysis of myocardial deformation at dobutamine stress echocardiography: an angiographic validation. J Am Coll Cardiol 2007;49:1651-9.

Jamal F, Kukulski T, D'hooge J, De S, I, Sutherland G. Abnormal postsystolic thickening in acutely ischemic myocardium during coronary angioplasty: a velocity, strain, and strain rate doppler myocardial imaging study. J Am Soc Echocardiogr 1999;12:994-6.

Jamal F, Kukulski T, Sutherland GR, Weidemann F, D'hooge J, Bijnens B, Derumeaux G. Can changes in systolic longitudinal deformation quantify regional myocardial function after an acute infarction? An ultrasonic strain rate and strain study. J Am Soc Echocardiogr 2002;15:723-30.

Jurcut R, Pappas CJ, Masci PG, Herbots L, Szulik M, Bogaert J, Van de Werf F, Desmet W, Rademakers F, Voigt JU, D'hooge J. Detection of regional myocardial dysfunction in patients with acute myocardial infarction using velocity vector imaging. J Am Soc Echocardiogr 2008;21:879-86.

Kim RJ, Fieno DS, Parrish TB, Harris K, Chen EL, Simonetti O, Bundy J, Finn JP, Klocke FJ, Judd RM. Relationship of MRI delayed contrast enhancement to irreversible injury, infarct age, and contractile function. Circulation 1999;100:1992-2002.

Lang RM, Bierig M, Devereux RB, Flachskampf FA, Foster E, Pellikka PA, Picard MH, Roman MJ, Seward J, Shanewise JS, Solomon SD, Spencer KT, Sutton MS, Stewart WJ. Recommendations for chamber quantification: a report from the American Society of Echocardiography's Guidelines and Standards Committee and the Chamber Quantification Writing Group, developed in conjunction with the European Association of Echocardiography, a branch of the European Society of Cardiology. J Am Soc Echocardiogr 2005;18:1440-63.

Leitman M, Lysyansky P, Sidenko S, Shir V, Peleg E, Binenbaum M, Kaluski E, Krakover R, Vered Z. Two-dimensional strain-a novel software for real-time quantitative echocardiographic assessment of myocardial function. J Am Soc Echocardiogr 2004;17:1021-9.

Medrano R, Lowry RW, Young JB, Weilbaecher DG, Michael LH, Afridi I, He ZX, Mahmarian JJ, Verani MS. Assessment of myocardial viability with 99mTc sestamibi in patients undergoing cardiac transplantation. A scintigraphic/pathological study. Circulation 1996;94:1010-7.

Mirsky I, Parmley WW. Assessment of passive elastic stiffness for isolated heart muscle and the intact heart. Circ Res 1973;33:233-43.

Mirsky I, Pasternac A, Ellison RC. General index for the assessment of cardiac function. Am J Cardiol 1972;30:483-91.

Miyatake K, Yamagishi M, Tanaka N, Uematsu M, Yamazaki N, Mine Y, Sano A, Hirama M. New method for evaluating left ventricular wall motion by color-coded tissue Doppler imaging: in vitro and in vivo studies. J Am Coll Cardiol 1995;25:717-24.

Oki T, Tabata T, Mishiro Y, Yamada H, Abe M, Onose Y, Wakatsuki T, Iuchi A, Ito S. Pulsed tissue Doppler imaging of left ventricular systolic and diastolic wall motion velocities to evaluate differences between long and short axes in healthy subjects. J Am Soc Echocardiogr 1999;12:308-13.

Pai RG, Gill KS. Amplitudes, durations, and timings of apically directed left ventricular myocardial velocities: I. Their normal pattern and coupling to ventricular filling and ejection. J Am Soc Echocardiogr 1998;11:105-11. 
Park YH, Kang SJ, Song JK, Lee EY, Song JM, Kang DH, Kim YH, Lee CW, Hong MK, Kim JJ, Park SW, Park SJ. Prognostic value of longitudinal strain after primary reperfusion therapy in patients with anterior-wall acute myocardial infarction. J Am Soc Echocardiogr 2008;21:262-7.

Pasquet A, Armstrong G, Beachler L, Lauer MS, Marwick TH. Use of segmental tissue Doppler velocity to quantitate exercise echocardiography. J Am Soc Echocardiogr 1999;12:901-12.

Quinones MA, Gaasch WH, Alexander JK. Echocardiographic assessment of left ventricular function with special reference to normalized velocities. Circulation 1974;50:42-51.

Rademakers FE, Rogers WJ, Guier WH, Hutchins GM, Siu CO, Weisfeldt ML, Weiss JL, Shapiro EP. Relation of regional cross-fiber shortening to wall thickening in the intact heart. Three-dimensional strain analysis by NMR tagging. Circulation 1994;89:1174-82.

Rodriguez L, Garcia M, Ares M, Griffin BP, Nakatani S, Thomas JD. Assessment of mitral annular dynamics during diastole by Doppler tissue imaging: comparison with mitral Doppler inflow in subjects without heart disease and in patients with left ventricular hypertrophy. Am Heart J 1996;131:982-7.

Sachdev V, Aletras AH, Padmanabhan S, Sidenko S, Rao YN, Brenneman CL, Shizukuda Y, Lie GR, Vincent PS, Waclawiw MA, Arai AE. Myocardial strain decreases with increasing transmurality of infarction: a Doppler echocardiographic and magnetic resonance correlation study. J Am Soc Echocardiogr 2006;19:34-9.

Schneider C, Bahlmann E, Malisius R, Hertting K, Antz M, Kuck KH. Tissue velocity imaging during dobutamine stimulation for assessment of myocardial viability: Segmental analysis in patients after myocardial infarction. Int J Cardiol 2005.

Serri K, Reant P, Lafitte M, Berhouet M, Le B, V, Roudaut R, Lafitte S. Global and regional myocardial function quantification by two-dimensional strain: application in hypertrophic cardiomyopathy. J Am Coll Cardiol 2006;47:1175-81.

Simonson JS, Schiller NB. Descent of the base of the left ventricle: an echocardiographic index of left ventricular function. J Am Soc Echocardiogr 1989;2:25-35.

Sjoli B, Orn S, Grenne B, Vartdal T, Smiseth OA, Edvardsen T, Brunvand H. Comparison of left ventricular ejection fraction and left ventricular global strain as determinants of infarct size in patients with acute myocardial infarction. J Am Soc Echocardiogr 2009;22:1232-8.

Skulstad H, Andersen K, Edvardsen T, Rein KA, Tonnessen TI, Hol PK, Fosse E, Ihlen H. Detection of ischemia and new insight into left ventricular physiology by strain Doppler and tissue velocity imaging: assessment during coronary bypass operation of the beating heart. J Am Soc Echocardiogr 2004;17:1225-33.

Skulstad H, Edvardsen T, Urheim S, Rabben SI, Stugaard M, Lyseggen E, Ihlen H, Smiseth OA. Postsystolic shortening in ischemic myocardium: active contraction or passive recoil? Circulation 2002;106:718-24.

Skulstad H, Urheim S, Edvardsen T, Andersen K, Lyseggen E, Vartdal T, Ihlen H, Smiseth OA. Grading of myocardial dysfunction by tissue Doppler echocardiography: a comparison between velocity, displacement, and strain imaging in acute ischemia. $J$ Am Coll Cardiol 2006;47:1672-82. 
Stanton T., Ingul C. B., Hare J. L., Leano R., Marwick T. H. Association of myocardial deformation with mortality independent of myocardial ischemia and left ventricular hypertrophy. JACC Cardiovasc Imaging 2009;2:793-801.

Stanton T., Leano R., Marwick T. H. Prediction of all-cause mortality from global longitudinal speckle strain: comparison with ejection fraction and wall motion scoring. Circ Cardiovasc Imaging 2009;2:356-64.

Stoylen A, Skjaerpe T. Systolic long axis function of the left ventricle. Global and regional information. Scand Cardiovasc J 2003;37:253-8.

Takayama Y, Holmes JW, LeGrice I, Covell JW. Enhanced regional deformation at the anterior papillary muscle insertion site after chordal transsection. Circulation 1996;93:585-93.

Uematsu M, Miyatake K, Tanaka N, Matsuda H, Sano A, Yamazaki N, Hirama M, Yamagishi M. Myocardial velocity gradient as a new indicator of regional left ventricular contraction: detection by a two-dimensional tissue Doppler imaging technique. J Am Coll Cardiol 1995;26:217-23.

Urheim S, Edvardsen T, Torp H, Angelsen B, Smiseth OA. Myocardial strain by Doppler echocardiography. Validation of a new method to quantify regional myocardial function. Circulation 2000;102:1158-64.

Vartdal T, Brunvand H, Pettersen E, Smith HJ, Lyseggen E, Helle-Valle T, Skulstad H, Ihlen $\mathrm{H}$, Edvardsen T. Early prediction of infarct size by strain Doppler echocardiography after coronary reperfusion. J Am Coll Cardiol 2007;49:1715-21.

Voigt J. U., Exner B., Schmiedehausen K., Huchzermeyer C., Reulbach U., Nixdorff U., Platsch G., Kuwert T., Daniel W. G., Flachskampf F. A. Strain-rate imaging during dobutamine stress echocardiography provides objective evidence of inducible ischemia. Circulation 2003;107:2120-6.

Voigt J. U., Lindenmeier G., Exner B., Regenfus M., Werner D., Reulbach U., Nixdorff U., Flachskampf F. A., Daniel W. G. Incidence and characteristics of segmental postsystolic longitudinal shortening in normal, acutely ischemic, and scarred myocardium. J Am Soc Echocardiogr 2003;16:415-23.

Voigt JU, Nixdorff U, Bogdan R, Exner B, Schmiedehausen K, Platsch G, Kuwert T, Daniel WG, Flachskampf FA. Comparison of deformation imaging and velocity imaging for detecting regional inducible ischaemia during dobutamine stress echocardiography. Eur Heart J 2004;25:1517-25.

Weidemann F, Dommke C, Bijnens B, Claus P, D'hooge J, Mertens P, Verbeken E, Maes A, Van de WF, De S, I, Sutherland GR. Defining the transmurality of a chronic myocardial infarction by ultrasonic strain-rate imaging: implications for identifying intramural viability: an experimental study. Circulation 2003;107:883-8.

Wilkenshoff UM, Sovany A, Wigstrom L, Olstad B, Lindstrom L, Engvall J, Janerot-Sjoberg B, Wranne B, Hatle L, Sutherland GR. Regional mean systolic myocardial velocity estimation by real-time color Doppler myocardial imaging: a new technique for quantifying regional systolic function. J Am Soc Echocardiogr 1998;11:683-92.

Willenheimer R., Cline C., Erhardt L., Israelsson B. Left ventricular atrioventricular plane displacement: an echocardiographic technique for rapid assessment of prognosis in heart failure. Heart 1997;78:230-6. 
Willenheimer R. B., Erhardt L. R., Cline C. M., Rydberg E. R., Israelsson B. A. Prognostic significance of changes in left ventricular systolic function in elderly patients with congestive heart failure. Coron Artery Dis 1997;8:711-7.

Yoshida T, Mori M, Nimura Y, Hikita G, Takagishi S, Nakanishi K, Satomura S. Analysis of heart motion with ultrasonic Doppler method and its clinical application. Am Heart J 1961;61:61-75.

Zhang Y, Chan AK, Yu CM, Yip GW, Fung JW, Lam WW, So NM, Wang M, Wu EB, Wong JT, Sanderson JE. Strain rate imaging differentiates transmural from nontransmural myocardial infarction; a validation study using delayed-enhancement magnetic resonance imaging. J Am Coll Cardiol 2005;46:864-71. 


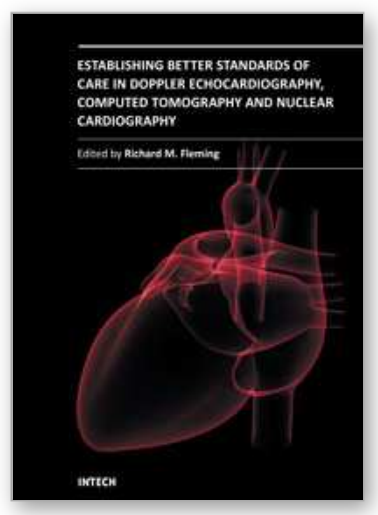

\author{
Establishing Better Standards of Care in Doppler \\ Echocardiography, Computed Tomography and Nuclear \\ Cardiology \\ Edited by Dr. Richard M. Fleming
}

ISBN 978-953-307-366-8

Hard cover, 260 pages

Publisher InTech

Published online 13, July, 2011

Published in print edition July, 2011

Since the introduction of Doppler Echocardiography, Nuclear Cardiology and Coronary CT imaging, clinicians and researchers have been searching for ways to improve their use of these important tools in both the diagnosis and treatment of heart disease. To keep up with cutting edge improvements in these fields, experts from around the world have come together in this book to provide the reader with the most up to date information to explain how, why and when these different non-invasive imaging tools should be used. This book will not only serve its reader well today but well into the future.

\title{
How to reference
}

In order to correctly reference this scholarly work, feel free to copy and paste the following:

Ola Gjesdal and Thor Edvardsen (2011). Tissue Doppler in Ischemic Heart Disease, Establishing Better Standards of Care in Doppler Echocardiography, Computed Tomography and Nuclear Cardiology, Dr. Richard M. Fleming (Ed.), ISBN: 978-953-307-366-8, InTech, Available from:

http://www.intechopen.com/books/establishing-better-standards-of-care-in-doppler-echocardiographycomputed-tomography-and-nuclear-cardiology/tissue-doppler-in-ischemic-heart-disease

\section{INTECH}

open science | open minds

\section{InTech Europe}

University Campus STeP Ri

Slavka Krautzeka 83/A

51000 Rijeka, Croatia

Phone: +385 (51) 770447

Fax: +385 (51) 686166

www.intechopen.com

\section{InTech China}

Unit 405, Office Block, Hotel Equatorial Shanghai

No.65, Yan An Road (West), Shanghai, 200040, China

中国上海市延安西路65号上海国际贵都大饭店办公楼 405 单元

Phone: $+86-21-62489820$

Fax: $+86-21-62489821$ 
(C) 2011 The Author(s). Licensee IntechOpen. This chapter is distributed under the terms of the Creative Commons Attribution-NonCommercialShareAlike-3.0 License, which permits use, distribution and reproduction for non-commercial purposes, provided the original is properly cited and derivative works building on this content are distributed under the same license. 